\title{
Livelihood Pattern and Health Seeking Behavior of Working Children in Khulna City
}

\author{
Md. Uzzal Hossain ${ }^{1}$ and Md. Jahidul Islam ${ }^{2 *}$ \\ ${ }^{1 \& 2}$ Sociology Discipline, Social Science School, Khulna University, Khulna, Bangladesh. \\ *Correspondence: jahidsoc14ku@gmail.com (Md. Jahidul Islam, Sociology Discipline, Khulna University, Khulna-9208, \\ Bangladesh).
}

\begin{abstract}
Working children are those groups of children under age 18 who engage in any form of work by which they are deprived of their childhood. Seeking behavior means the medical attention given to seeking or injured person or animal for their better health condition. The goal of the revision is to explore the livelihood pattern and health pursuing behavior of the working children in Khulna city. The study is explanatory and descriptive in nature and the survey method is conducted with an interview schedule. The study is carried out on 166 respondents through simple random sampling. The findings indicate that working children come from poor families. They have to work to support their family at an early age. This study reveals that around 42 percent of the participants belong to the age group of 13-15 years old. Their educational qualification is also very low, around 54 percent of the participants enrolled in class 1 to 5 but a great amount of participants has no formal education. The respondents live in the urban area but their corporeal state is not good. The working children do not get enough food for their survival. They are not aware of their own rights due to illiteracy. Also, majority of the participants do not get proper facilities from working place and around 68 percent are tortured in graft places. They are discriminated against by their employee. Even maximum of them (64.5\%) do not use safety protection during their work time consequently sometimes they are injured physically. Besides these, they suffer from various diseases but they do not get suitable cures due to poverty in addition to illiteracy. Working children face different sorts of abuse in their working place $(65.7 \%)$. Though they get help from government there is very little for their betterment. So government and NGOs can play a very vital role to remove this discrimination besides social awareness is very far necessary to combat this problem.
\end{abstract}

Keywords: Livelihood, Health, Working, Children, Khulna city, NGOs, Education, and Income.

\section{INTRODUCTION:}

The global context of child work is increasing with a very rapid number in recent time. Child is engaging different types of work in search of their livelihood. Research of UNICEF and the International Labor Organization (ILO) shows that children are involved in more than 400 types of work, with 47 of these identified as 'hazardous'. Various risk features for health are initiates in their working place (BBS, 2015). Working children remain to face a lot of problems in their workplace. This study links the UniversePG I www.universepg.com livelihood pattern and health pursuing behavior of working children in the Khulna City Corporation area. Malnutrition was more predominant among working children as $33 \%$ health position of children is mostly regarding an issue at present-days because it happened more among working children mostly its unhygienic and polluted environment (Hai, 2014).

The devastating majority of working children are found in emerging states. Working Children are mainly created from those families who are fighting 
against poverty and trying to advancement their family condition. Children from those families do not become workers cheerfully but the decline of socioeconomic conditions armies them to be child workers (Goswami, 2012). Although Bangladesh's financial statement for less than 2 percent of the world population, it is the home of 6.6 million working children, accounting for more than 5 percent of the world's working child population numbering 120 million. In Bangladesh children are found working in almost all the working sectors are most susceptible. Many of them work 48 hours a week on average, producing less than 500 takas per month. A great quantity of children works in several occupations that are perilous and hazardous (Hossain, 2015).

The current work was acknowledged to gather overall material on the health status of working children of Khulna city. Being the most settled and poverty distressed states of the world, the health problem of working has become lone of the major concerns for the supervision and the people of Bangladesh (Salma and Ray, 2014). According to BBS, among the children, several working children are set up in refuse sites in urban Bangladesh and majority lived under the poverty line or dangerous levels of poverty situation. Many occupations contain working in hazardous conditions that endanger the child's physical or emotional health and decent development through unsafe environments, precarious or overly-long working hours (BBS, 2013). Bangladesh is a heavily populated country. Different sorts of the population live here but minority of them are exposed. Child labor is a public phenomenon here (Maria, 2016). The quantity of child work is accumulative in urban areas at a startling rate and they are finished hazardous situations to survive. The dominance of children at work proliferations in latest years and has become a stark problem during the world, especially in many poor developing countries of Asia, Africa (Korme, 2017). Being one of the greatest heavily populated and poverty-stricken countries in the realm, the problem of children at work has become the main apprehensions for the administration and the people of Bangladesh (Save the children, 2015). Numerous juvenile workers are found in action in urban Bangladesh and majority of them survived under the poverty line or exciting levels of poverty situation. Childhood influence is very important to take the development approaches for any nation. Still a considerable number of young aged people are UniversePG I www.universepg.com including in economic activities at an early age. In Bangladesh, the total quantity of children matured 514 years is 35.06 million among which working children is around 5.05 million (Marufa et al., 2019).

Various commended actions are required to reduce corruption and to expand the socio-economic situation of the teenagers at work in municipal areas. Thus to detect all the problem conditions of adolescent labor in their adaptation method in the urban area mainly in the metropolitan city of Bangladesh, the study of the teenagers at work in urban areas does intellect its necessity (Animesh et al. 2019). Investigation on the 'situation analysis and need assessment of working children' gets the importance to reveal the current existing conditions of the subsequent generation of the country. Because of the huge child workers' existence in urban areas the study needs to be shown in urban location as a recognized metropolitan city like Khulna to fulfill its consequence (Kalam, 2007). So this work is very urgent to emphasis on the livelihood pattern and health seeking deeds of the child who were labors at an early age in our humanity, to specify the barriers for celebrated future life, to discover the present situation of them $\&$ to concentration on their recent positions.

\section{MATERIALS AND METHODS:}

This revision is cross-sectional study works shown at ward no. 21 in Borya slum area and ward no. 24 in Niralaarea under Khulna City Corporation of Bangladesh. The study area was nominated purposively and working children existing in this area aged the age group 9 to below 18 years were pain-staking as the population of this work. Since itwas difficult to accumulate information almost fromall the working childrenexist in in those areas, we selected a minornumber of partakers (sample) analytically for our survey. The participants were nominated through simple random sampling technique (lottery method without replacement) expending the sample frame obtained from the particular ward com-mission offices. Using the following method of sample size determination, a model size 166 of designated considering a confidence interval 5.05 then, in accordance to area ratio of the population in selected region, 166 working child were selected proportionately as the model of the study.

$S S=\frac{Z^{2} x \mathrm{P}(1-\mathrm{P})}{C^{2}}$ 
$S S_{i}=\frac{\mathrm{SS}}{1+\frac{S S-1}{P o p}}$

Here,

$S S=$ Sample Size

$S S_{i}=$ Sample Size, according to Population

$\mathrm{Z}=$ Confidence Level (i.e. 1.96 for $95 \%$ confidence level)

$\mathrm{P}=$ Percentage of Picking a Choice (i.e. 0.5 used for sample size needed)

$\mathrm{C}=$ Confidence Interval (i.e. 5.05)

Pop $=$ Population

\section{Calculation of Sample Size}

$$
\begin{aligned}
& \mathrm{SS}=\frac{(1.96)^{2} \times 0.5(1-0.5)}{(0.0505)^{2}} \\
& =\frac{3.842 \times 0.5 \times 0.5}{0.00255025} \\
& =\frac{0.9604}{0.00255025} \\
& =376.59
\end{aligned}
$$

\section{Correction for Finite Population}

$$
\begin{aligned}
& S S_{i}=\frac{\mathrm{sS}}{1+\frac{\mathrm{ss}-1}{\mathrm{pop}}} \\
& =\frac{376.59}{1+\frac{376.59-1}{296}} \\
& =\frac{376.59}{1+\frac{375.59}{296}} \\
& =\frac{376.59}{1+1.2688851351} \\
& =\frac{376.59}{2.2688851351} \\
& =165.98 \\
& =166
\end{aligned}
$$

Anin-depth review of pertinent literature was done for organising the designed interview schedule used in this work. All the information was together through the September and October 2019 through face-to-face interviews. The data composed were man-aged and analysed through Statistical Packages for Social Sciences (SPSS) version 21 software. These variables were found significant in around of the previous studies (Marufa et al., 2019; Animesh et al., 2019; Korme, 2017; Maria, 2016; Salma and

\begin{tabular}{|c|c|c|c|}
\hline Variables & Categories & Frequency & Percent \\
\hline \multicolumn{4}{|c|}{ Age Structure } \\
\hline & $9-12$ & 44 & 26.51 \\
\hline & $13-15$ & 69 & 41.57 \\
\hline & $16-18$ & 53 & 31.93 \\
\hline \multicolumn{4}{|c|}{ Education } \\
\hline & Illiterate & 40 & 24.08 \\
\hline & Primary & 50 & 30.12 \\
\hline & Secondary & 76 & 45.8 \\
\hline \multicolumn{4}{|c|}{ Religion } \\
\hline & Muslim & 115 & 69.3 \\
\hline & Non-Muslim & 51 & 30.7 \\
\hline \multicolumn{4}{|c|}{ Fathers occupation } \\
\hline & Day labor & 75 & 45.8 \\
\hline & Rickshaw & 70 & 42.2 \\
\hline & Petty trader & 20 & 12.0 \\
\hline \multicolumn{4}{|c|}{ Mothers occupation } \\
\hline & Day labor & 14 & 8.4 \\
\hline & House servant & 42 & 25.3 \\
\hline & Housewife & 110 & 66.3 \\
\hline \multicolumn{4}{|c|}{ Respondent income } \\
\hline & $1000-4000$ & 96 & 57.8 \\
\hline & $4001-8000$ & 64 & 38.6 \\
\hline & $8001-12000$ & 6 & 3.6 \\
\hline
\end{tabular}
Ray, 2014). For ethical clearance, the research data were accepted by ethical permission from the relevant respondents and the respondent participant voluntarily. Confidentiality was maintained so that no information no information would be linked to specific respondent.

\section{RESULTS:}

Table 1: Demographic and socio-economic information of the participants (Source: Field Survey, 2019).

The demographic and socioeconomic features of the respondents show in Table 1 Findings reveal that around 42 percent of the respondents belong to the age of 13 to 15 , around 32 percent of whom are belong to 16 to 18 and the repose of them belong to 9 to 12 years. It states that round 54 percent of the participants are belong to class 1 to 5 and around 46 percent of who are belong to class 6 to 10. Around 69 percent respondents are Muslims and around 31 percent are non-Muslims. So here the scenario shows that majority of the participants are Islamic believers while very few belonged to the religious belief of Hinduism, Christianity and others. Besides, that everywhere 42 percentages of the respondent's father day labour, around 42 percent of them are rickshaw/ van puller whereas only 12 percent of them are petty trader. Moreover, it states that about 66 percentage of the respondent's mother are housewife, about 25 percent of them are house servant and about 8 percentages of them are day labour. This table demonstrates that around 58 percent of them earn BDT 1000 to 4000 take each month, around 39 percent earn 4001 to 8000 taka per month and rest of them earn 8001 to 12000 taka per month. The mean earnings of the respondents is about BDT 4648 taka. 


\section{Bivariate analysis}

Table 2: Information about Socio-economic Determinants affecting the covariates (Source: Field Survey, 2019).

\begin{tabular}{|c|c|c|c|c|c|c|}
\hline \multicolumn{7}{|c|}{ Factors Affecting Educational and Using Toilet } \\
\hline \multicolumn{2}{|c|}{ Independent Variables (Covariates) } & \multicolumn{3}{|c|}{ Use of toilet } & \multirow[t]{2}{*}{$\chi^{2}$ (df) } & \multirow[t]{2}{*}{ p value } \\
\hline \multirow[t]{4}{*}{ Year of schooling } & & Sanitary & Unsanitary & Total & & \\
\hline & Illiterate & $16.0 \%$ & $21.2 \%$ & $18.1 \%$ & 10.067 & $<.007 * * *$ \\
\hline & Primary & $48.0 \%$ & $65.2 \%$ & $54.8 \%$ & & \\
\hline & Secondary & $36.0 \%$ & $13.6 \%$ & $27.1 \%$ & & \\
\hline \multicolumn{7}{|c|}{ Factors Affecting Educational and Taking Protection by Employer } \\
\hline \multirow[t]{5}{*}{ Year of schooling } & & \multicolumn{2}{|c|}{ Protection by Employer } & & & \\
\hline & & Yes & No & Total & & \\
\hline & Illiterate & $5.6 \%$ & $21.1 \%$ & $15.3 \%$ & & \\
\hline & Primary & $57.4 \%$ & $61.1 \%$ & $59.7 \%$ & 11.050 & $<.005 * * *$ \\
\hline & Secondary & $37.0 \%$ & $17.8 \%$ & $25.0 \%$ & & \\
\hline \multicolumn{7}{|c|}{ Factors Affecting Nature of Work and assistance from NGOs } \\
\hline \multirow[t]{5}{*}{ Nature of Work } & & \multicolumn{2}{|c|}{ Help From NGO } & & & \\
\hline & & Yes & No & Total & & \\
\hline & Permanent & $48.5 \%$ & $69.4 \%$ & $53.0 \%$ & 7.168 & $.028 * *$ \\
\hline & Temporary & $40.0 \%$ & $30.6 \%$ & $38.0 \%$ & & \\
\hline & Sessional & $11.5 \%$ & $0.0 \%$ & $9.0 \%$ & & \\
\hline \multicolumn{7}{|c|}{ Factors Affecting Diseases and Use of Toilet } \\
\hline Diseases & & \multicolumn{2}{|c|}{ Use of toilet } & & & \\
\hline & & Hygienic & Unhygienic & Total & & \\
\hline & Fever & $52.0 \%$ & $25.8 \%$ & $41.6 \%$ & 19.999 & $<.000 * * *$ \\
\hline & Diarrhoea & $11.0 \%$ & $13.6 \%$ & $12.0 \%$ & & \\
\hline & Cholera & $13.0 \%$ & $40.9 \%$ & $24.1 \%$ & & \\
\hline & No Diseases & $24.0 \%$ & $19.7 \%$ & $22.3 \%$ & & \\
\hline \multicolumn{7}{|c|}{ Factors Affecting Educational and Seek treatment } \\
\hline \multirow[t]{2}{*}{ Year of schooling } & \multicolumn{3}{|c|}{ Seek treatment } & & & \\
\hline & Alopatheth & Homeopathi & Kabiraj & Total & Exact Test & \\
\hline Illiterate & $16.0 \%$ & $12.5 \%$ & $41.2 \%$ & $18.1 \%$ & 8.057 & $<.050 * *$ \\
\hline Primary & $53.6 \%$ & $70.8 \%$ & $41.2 \%$ & $54.8 \%$ & & \\
\hline Secondary & $30.4 \%$ & $16.7 \%$ & $17.6 \%$ & $27.1 \%$ & & \\
\hline
\end{tabular}

Notes; $\chi 2=$ Pearson chi-square; ** Significance level at $5 \%$ and $* * *$ Significance level at $1 \%$

The influence of education of the participants on use of toilet through are direct, in low year of schooling it is difficult to use hygienic toilet for their better health. The associationamong education and use of toilet is observed in the above Table. The findings represent that use of toilet was highly associated with their year of schooling. The difference was statistically signified $\left(\mathrm{x}^{2}=10.067 ; \mathrm{P}<.007\right)$. The result of education of the respondents on use of protection through are direct, in low year of schooling it is difficult to use protection for their safety. The connection between education and the usage of protection is tested in the above table. The findings represent that use of protection was highly associated with their year of schooling. The difference was statistically signified $\left(\mathrm{x}^{2}=11.050 ; \mathrm{P}<.005\right)$. The UniversePG I www.universepg.com things of nature of work of the participants on help from NGOs through are direct; in temporary job it is difficult to get help from NGOs. The affiliation between nature of work and help from NGOs is examined in the above table. The findings represent that help from the NGOs were highly associated with the nature of works. The difference was statistically signified ( $\mathrm{x} 2=7.168 ; \mathrm{P}<.028)$. The effect using toilet of the participantson diseases through are direct, in using unhygienic toilet it is difficult to lead better health. The correlation between diseases and use of toilet is examined in the above table. The findings represent that diseases were highly associated with their use of toilet. The difference was statistically signified $\left(\mathrm{x}^{2}=19.999 ; \mathrm{P}<.000\right)$. In addition, for the asymmetrical significant is .000 express the strong 
connection between effects of diseases with use of toilet. The effect of education of the respondents on health seeking treatment through are direct, in low year of schooling it is difficult to seek treatment for their health. The correlation between education and health seeking behaviour is examined in the above table. The findings represent that seeking treatment was highly associated with their year of schooling. The difference was statistically signified (Fisher's exact test $=8.057 ; \mathrm{P}<.050)$.

\section{DISCUSSION:}

In this chapter, under the title of basic information of the occupied children, the data showed that, mainstream of the respondents' education level was under 54.2 percent and the second 45.8 percent was under secondary education level. This study stated that about 81 percent of the respondent's family head is father whereas about 18 percentages is mother. It depicts that maximum of the respondents' lives in the town areas and it is about 72 percent whereas about 28 percent of the respondents live in the rus-tic areas (ICDDRB, 2019). It also stated around 58 percent of them earn 1000 to 4000 tk per month and the average recurrent family earnings is around 13995 taka. Under the title of working environment of child worker, around 32 percent of the respondents are day labour, around 24 percent of whom are hotel boy and most of them (around 56 percent) are full time employee. And around half of them are permanent worker. The study also depicts that the relationship of the child worker with their employee is not good. Most of the time they are deprived and dominated by their employee. Besides most of them do not use protection or safety guard during their work time because of lack of opportunity and education that is why there is big possibility of being injured (MacKian, 2003). On the other indicator, they do not get proper medical assistance by their employee. Most of the working child gives part of their income to their family. Here it stated that majority of them changed their occupation due to low income and torture in their labour place. Food nutrition and healthcare facilities stated that 39 percent of them take meal with their parents, around 34 percent of them with employers, around 24 percent of them self and the repose of them are with relatives and others. Here 55 percent of the respondent's sources of water are supply water and around $45 \mathrm{f}$ the respondent's sources of water is deep tube-well. This section showed that around 60 percentages of UniversePG I www.universepg.com the respondents use sanitary toilet and maximum of them share their toilet with others (Asraful and Datta, 2019). As they share their toilet with others that is why there is a huge possibility of being affected with several diseases and is concerning that most of them suffer from some diseases such as fever diarrhoea and cholera and around 72 percent of the respondents seek treatment from allopathic. It stated that around 48 percent of their parents bear their cost, around 36 percent are self. Besides these addiction habit is very concerning issue in recent time and this work showed that more than half of the participants have addiction habit. The concerns of child labor, the data depicted that around 68 percent of the participantsare punished in their workplace which is very concerning issue in recent time, sometimes they also arrested and tortured by police as well. Besides these many children are so much enthusiastic to sexual intercourse now a day and the data depict that around 20 percent of who are experienced with sexual intercourse before their suitable age (Islam and Islam, 2021; Syed and Normand, 2012).

Government and NGOs initiatives of child labor, the data stated the government and NGOs initiatives of juvenile labor for their betterment. The data depict that around 73 percent of the total respondents do not get any help from government and NGOs. It also stated that around 27percent of them get help from government and the type of help is relief based (Syed and Kielmann, 2012). Most of the occupied children originate from poor families. They are imposed to leave their families due to scarcity, hunger, neglect, and sometimes abuse. They are expanded in risky jobs. The mainstream of the working children is unaware of the only primary passed and most of them do not read and write. They cannot go to school due to poverty. So they do not conscious of their basic rights. Working children work in different homes like a hotel, shop, day labor, welding, tailors and so on. When a child makes dangerous and unsatisfactory jobs from an early age, he or she gets a very little chance to acquire skills thus they remained unskilled. So they do not get better jobs. Working children have the precise to access nutrition, medical care and education to be a participant of society. But the majority of the working children are unhealthy, badly continued and without education (Syed and Adams, 2000). Occupied children are insolvent of nutrition, food, required for healthy progress and expansion. Their existing condition is unhygienic 
due to the mass of waste lying around, lack of safe drinking water, simple air and noise pollution. The respondents live in employer houses, working place or low hired slum areas and they face many problems. They suffer from diverse types of diseases are diarrhea, meal ease, headache, cough, and other diseases. Due to a deficiency of money, they cannot deal with their diseases. Many diseases and illnesses are often ignored by his or her family or him or her self-due to poverty. Some working children usually take little anticipative care, seeking assistance, only when the problem becomes serious (Mustaque and Bhuiya, 2003). Many of them are drug-addicted. Some working children do not lead normal life due to drug and also many of them faced economical or physical punishment in working place and most helpless situations for working girls being abused in different situations. In joining a job they neither get no concentration from the employer about the rule of child labor nor aid nor support from Govt. and NGOs. In terms of their interaction with social facilities and involvement in the labor forces, they are the most disadvantaged.

\section{CONCLUSION:}

Today's child is tomorrow's future. They stand the most valuable wealth of every nation. But inappropriately they are affianced in various works owing to poverty. Teen labor is renowned as a global health problem. And it is regret that this problem is very much severe in our country. It is easy in the Industrialized world to think child labor a problem of the past, but recent news stories have brought the matter back under the spotlight. In the recent years the rate of child labor is growing day by day in our country. It is identicalessential to control this tendency otherwise it would damage our overall development. Without controlling the child labor situation, it is quite impossible to ensure country's progress. But to control the child labor situation is not an easy task. If we want to minimize child labor propensity then we need to resistor its related aspects such as poverty, family inefficiency, over urbanization, over industrialization etc. Without the help of general people, it is quite impossible to remove this situation only for Government. Various NGOs also work to remove child labor situation from our country, but their power is limited. It is also very much necessary to combination between Government Organization and Non-Government Organization. Further researches are also needed to recognize the present situation of UniversePG I www.universepg.com child labor in our country. To control this problem, it is required to afford these facilities is access to health care facilities, access to clean water, improved educational facilities, to control fertility etc. If we want to improve these facilities, then we determination be gifted to control the acute problem from our country.

\section{ACKNOWLEDGEMENT:}

The researcher greatly obliged his supervisor, Dr. Md. Jabbar, Professor, Sociology Discipline, Khulna University for his kind supervision, intellectual motivation, valuable advice and continuous guidance. The researcher would not be able to accomplish this paper without his careful readings of many drafts, rapid and practical feedback, and guidance that he provided. Alongside, the researcher also grateful to all his teachers of sociology discipline who have supported his by their advices and guidance many times in his study period.

\section{CONFLICTS OF INTEREST:}

The researcher declares no possible conflict of interest concerning the study, data collection \& analysis, authorship, and/or publication of this present article.

\section{REFERENCES:}

1) Alem, H. W., \& Laha, A. (2016). Livelihood of path children and the role of social intervention. Child Development Research, 13.

2) Animesh Biswas, M. D. (2019). Working to stay healthy', health-seeking behaviour in Bangladesh's urban slums: a qualitative study. BMC public health volume .

3) Anker, R. (2008). The economics of child labour: A framework for measurement. International Labour Review. https://doi.org/10.1111/j.1564-913X.2000.tb0020 4.x

4) Anker. (2015). The economies of child labor: A framework for measurement. International Labor Review, 257-280.

5) Anwar. (2006). Studied on solid waste management in Dhaka City, Bangladesh

6) Asraful Kabir, R. D. (2019). Health shocks, care-seeking behaviour and coping strategies of extreme poor households in Bangladesh's Chittagong hill tracts. BMC public health. https://doi.org/10.1186/s12889-019-7335-7 
7) BBS, (2013). Child labor in Bangladesh statistical pocketbook. Bangladesh Bureau of Statistics Dhaka, Bangladesh.

8) Children, S. t. (2015). Malnutrition in Bangladesh: Harnessing social protection for the most vulnerable. London, UK: The Save the children fund 2015. https://doi.org/10.3329/ajmbr.v5i4.45260

9) Coleman, J. (1998). Foundations of social theory. Harbard university press.

10) Coleman, j. (1990). Foundations of social theory. Harvard university press. https://doi.org/10.1093/sf/69.2.625

11) Cusianovich, S. a. (2004). Working children: Building an identity. Manthoc.

12) Dawson, C. (2002). Practical research methods. New Delhi: UBS Publishers Distributors. https://www.amazon.com/Practical-Research-Me thods-Catherine-Dawson/dp/1857038290

13) Dawson, D. C. (2002). Practical research methods: A user-friendly guide to mastering research techniques and projects. 3 Newtec Place, Magdalen Road: Oxford OX4 1RE, United Kingdom.

14) Enayetullah, \& Sinha. (1995). Waste concern technical documentation, Urban solid waste management scenario of Bangladesh: Problems and prospects. 5-13.

15) Ferrous, (1999). Studied on solid waste management in Nirala residential area, Khulna.

16) Goswami, S. (2012). Health and child development paradox: Findings from Raipur slums. Global journal of human social sceince.

17) Hai, M. A. (2014). Problems faced by the street children: A study on some selected places in Dhaka City, Bangladesh. International journal of scientific and tecnology research. http://hdl.handle.net/10138/159050

18) Hossain, M. Z. (2015). Rural-urban migration in Bangladesh: A micro-level study. Discover the world's research.

19) ICDDRB, I. C. (2019). Slum health in Bangladesh: Insights from health and dem-graphic surveillance. Dhaka: Health systems and population studies division (icddrb).

20) ILO. (2014). Child Labor: How the challenge is being met. International Labor Review, 233257.

21) Islam MJ and Islam M. (2021). Determinants of early marriage among the women: a study on
Khulna district, Asian J. Soc. Sci. Leg. Stud., 3(3), 89-98.

https://doi.org/10.34104/ajssls.021.089098

22) Islam. (2012). Street and working children in Bangladesh. Department of social work. shahjalal university of science and technology, Sylhet, Bangladesh.

23) Islam, M. S., Rahman, M. E., \& Khatun, R. (2013). Street children struggle for survival wheren protection of human resource development: (A study on Khulna City, Bangladesh). International journal of scientific \& technology research, 2(11).

http://www.ijstr.org/paper-references.php?ref=I JSTR-1113-7581

24) Jahan, N. A., Howlader, S. R., Sultana, N., Ishaq, F., Sikder, M. Z. H., \& Rahman, T. (2015). Health care seeking behavior of slumdwellers in Dhaka City.

25) Jary, D. j. a. J. (1991). Collins dictionary of sociology. Harper Collins pulisher.

https://www.amazon.com/Collins-Dictionary-So ciology-David-Jary/dp/0004708040

26) Kalam, I. M. S. ( 2007a). Glimpse on child labor: A study on child labor situation in Dhaka City Corporation area BRAC university journal, 4, 19-29.

27) Korme, A. (2017). A study on the prevelemce of child labor in Africa: A case study on kechene neighborhood, Ethiopia. Addis Ababa: Addis Ababa university.

28) Kothari, C. R. (2004). Research methodology: Methods and techniques. New Dellhi: New age international publishers.

https://doi.org/10.4236/ajibm.2014.412080

29) Latif, M. B. (2016). Socio-economic and health status of slum dwellers of the Kalyanpur slum in Dhaka city. The Bangladesh journal of scientific research.

https://doi.org/10.3329/bjsr.v29i1.29760

30) Lewis, (2010). A study of beggars characteristics and attitude of people towards the phenomenon of begging in the City of Shiraz. Journal of applied sociology, 39.

31) MacKian, S. (2003). A review of health seeking behaviour: Problems and prospects. Health systems development, $U K$.

https://doi.org/10.4236/ojepi.2019.91004 
32) Maria Quattri, K. W. (2016). Child labour and education: A survey of slum settlements. London: Overseas development institute.

33) Marufa Sultana, A. R. (2019). Prevalence, determinants and health care-seeking behavior of childhood acute respiratory tract infections in Bangladesh. Global pediatric health. https://doi.org/10.1371/journal.pone.0210433

34) Md. Sirajul Islam, M. E. (2013). Street children struggle for survival where protection of human resource development: A study on Khulna City, Bangladesh. International journal of sceincetific \& tecnology research.

35) Mohajan, H. K. (2014). Child Rights in Bangladesh. Journal of social welfare and human rights.

36) Murtaza, G. (2007). Environmental problems: A spatio-household level study. Khulna University, Bangladesh.

37) Mushtaque Chowdhury, A. B. (2003). Changing health-seeking behaviour in Matlab, Bangladesh: do. Oxford university press. https://doi.org/10.1093/heapol/czg037

38) Nahid Akhter Jahan, S. R. (2015). Health care seeking behavior of slum-dwellers in Dhaka City: Results of a household survey. Dhaka: Institute of health economics, university of Dhaka. https://doi.org/10.1371/journal.pone.0233635

39) Nguyen, H. T. L., \& Evans, R. G. (2000). A study on health \& social needs of waste pickers in Vietnam.

40) NIPORT, I. (2015). Bangladesh rrban health survey 2013 final report. Chapel Hill, USA: Measure evaluation.

41) Patil, S. C., \& Dixit, P. (June 19, 2018). Health seeking behavior among 0-5 years of children in diarrhea in rural wardha district, Mahara- shtra. J. primary healthcare: Open access, 8(2), 299.

https://doi.org/10.4172/2167-1079.1000299

42) Pravin, N., Yerpude, Keerti, S., Jogdand, Shah, H. J., \& Thacker, B. K. (2017). A study of factors which determine health seeking behavior of mothers for their under five children in rural area of Gujarat. International of community medicine and public health, 4.

43) Programme Quality Learning and Research Unit (PQLR), I. R. (2014). Elimination of hazardous child labour. Elimination of hazar-dous child labour (EHCL).

44) Rahman, M. M., \& Ali, M. A. ((2005). Waste management and environmental pollution in Bangladesh, Dhaka 429- 435.

https://doi.org/10.1016/j.heliyon.2019.e02145

45) Salma Ahmed, R. R. (2014). Health consequences of child labour in Bangladesh. Demographic research.

46) Syed Azizur Rahman, C. N. (2012). Healthcareseeking behaviour among the tribal people of Bangladesh: Can the current health system really meet their needs? Springer.

47) Syed Azizur Rahman, T. K. (2012). Healthcareseeking behaviour among the tribal people of Bangladesh. Journal of health population and nutrition .

48) Syed Masud Ahmed, A. M. (2000). Gender, socioeconomic development and health-seeking behaviour in Bangladesh. Social science \& medicine.

https://ideas.repec.org/a/eee/socmed/v51y2000i3p 361-371.html

49) The study on the solid waste management in Dhaka City, (2005). Dhaka: Dhaka City Corporation.

Citation: Hossain MU., and Islam MJ. (2022). Livelihood pattern and health seeking behavior of working children in Khulna city, Br. J. Arts Humanit., 4(2), 32-39. https://doi.org/10.34104/bjah.022032039 @ @ 